\title{
Artemisinin is highly soluble in polyethylene Glycol 4000 and such solution has multiple biological effects*
}

\author{
Yu Bao ${ }^{1,2}$, Zhi Li1,2四, Si-Hao Chen 1,2, Li-Zhi Gao1,2, Zu-Lan Liu'1,2, Lan Cheng ${ }^{1,2,3}$, Yan Peng ${ }^{1,2}$, \\ Xiao-Ling Tong ${ }^{1,3}$ and Fang-Yin Dai ${ }^{1,2,3 区}$ \\ 'State Key Laboratory of Silkworm Genome Biology, Southwest University, Chongqing, China; ${ }^{2}$ Chongqing Engineering Research Center of \\ Biomaterial Fiber and Modern Textile, College of Textile and Garment, Southwest University, Chongqing, China; ${ }^{3 K}$ ey Laboratory of Sericultural \\ Biology and Genetic Breeding, Ministry of Agriculture, College of Biotechnology, Southwest University, Chongqing, China
}

\begin{abstract}
Artemisinin has a significant role in treatment of malaria, as well as effective anti-inflammatory and anti-cancer activities. However, such problems as poor water solubility and easy recrystallization limit its application. In this study, polyethylene glycol, a solvent which is widely used in pharmaceutics, was introduced to prepare an artemisinin dissolution. Under the action of hydrogen bonding in $12 \%$ polyethylene glycol 4000 solvent, the maximum solubility of artemisinin could reach up to $1 \mathrm{mg} / \mathrm{mL}$. Meanwhile, biological functions of such artemisinin solution were evaluated. The obtained artemisinin solution had a significant inhibitory effect on Gram-positive bacteria, Gram-negative bacteria and fungi. As for the anti-inflammatory property, $0.031 \mathrm{mg} /$ $\mathrm{mL}$ artemisinin solution had an obvious inhibitory effect on nitric oxide release in inflammatory cells, and the survival rate of cells was greater than $50 \%$. Low concentration of the obtained artemisinin solution $(0.031 \mathrm{mg} / \mathrm{mL})$ had no significant cytotoxicity, while it displayed selective inhibition in cancer cells. $I C_{50}$ for human hepatoma cells BEL-7404, SMMC7721 and Hep G2 is $0.0016 \mathrm{mg} / \mathrm{mL}$, $0.0084 \mathrm{mg} / \mathrm{mL}$ and $0.0541 \mathrm{mg} / \mathrm{mL}$, respectively. In conclusion, the $12 \%$ PEG4000-assisted artemisinin solution has a good biological effect and it can be further applied in pharmaceutics, biomaterials and medicine.
\end{abstract}

Key words: artemisinin, solubility, antimicrobial, anti-inflammatory, anticancer

Received: 19 February, 2020; revised: 03 April, 2020; accepted: 07 April, 2020; available on-line: 18 May, 2020

๑e-mail: fydai@swu.edu.cn (F-YD) tclizhi@swu.edu.cn (ZL)

*Acknowledgements of Financial Support: This research was funded by grants from the National Natural Science Foundation of China (No. 31830094, No. 31472153); the Hi-Tech Research and Development 863 Program of China (grant No. 2013AA102507); the Funds of China Agriculture Research System (No. CARS-18-ZJ0102), and the open fund of State Key Laboratory of Silkworm Genome Biology (No.sklsgb161718-7).

Abbreviations: ART, artemisinin; PEG, polyethylene glycol; ROS reactive oxygen species; $\mathrm{MIC}$, minimum inhibitory concentration; SDS, sodium dodecyl sulphate; PVP, polyvinylpyrrolidone; DMSO, dimethyl sulfoxide; DMEM, Dulbecco's modified eagle's medium $\mathrm{IC}_{50}$ inhibitory concentration 50\%; LPS, lipopolysaccharide; MTS 3-[4,5-dimethylthiazol-2-yl]-5-[3-carboxymethoxyphenyl]-2-[4-sulfophenyl]-2H-tetrazolium, inner salt.

\section{INTRODUCTION}

ART, isolated from the medicinal plant Artemisia annua $L_{\text {. }}$, is a sesquiterpene lactone compound with a peroxide bridge structure (You-You et al., 2015). The most effective use of ART is in treatment of malaria, hav- ing reduced global malaria mortality by $50 \%$ and infection rates by $40 \%$ over the past decade. For this great achievement Youyou Tu was awarded the 2015 Nobel Prize in Physiology or Medicine ( $\mathrm{Tu}, 1999)$. It is proven that ART exerts a unique mechanism in treatment of malaria (Van Agtmael et al., 1999). In addition, some other functions of ART have been reported. ART can kill a variety of parasites (Abou Rayia et al., 2017), inhibits viral replication and proliferation (Paeshuyse et al., 2006), and inhibits the inflammatory response ( $\mathrm{Li}$ et al., 2012). Also, ART has some obvious effects on some cancer cells and tumors, including inhibition of growth and proliferation of ovarian cancer (Li et al., 2016), human lung cancer (Ganguli et al., 2014), gallbladder cancer (Jia et al., 2016), colon cancer (Riganti et al., 2009), and inhibition of angiogenesis during tumor growth (Abba et al., 2018).

However, ART has a poor water solubility (only $82.4 \mu \mathrm{g} / \mathrm{mL}$ in water at $37^{\circ} \mathrm{C}$ ) (Gao et al., 2013). Medium polarity solvents, such as chloroform and acetone, have good ART dissolving ability, but they are biologically toxic (Liu et al., 2009). Moreover, ART can easily crystallize during the extraction process and this crystallized ART is very difficult to resolve or to store for a long time after extraction, and this greatly restricts the application of ART (Svensson et al., 1999; Wong \& Yuen, 2001). A great deal of studies has been conducted to solve this problem, such as preparing ART derivatives with good water solubility (Barradell \& Fitton, 1995; Wang \& Yi, 2008). The relative problems, such as the complicated process, time-consuming period and high cost, should be also considered. Another way to approach this problem is to increase solubility of ART in a solution with a co-solvent. ART is generally dissolved in DMSO (Abou Rayia et al., 2017). However, DMSO at a concentration above $1 \%$ significantly affects cell growth and promotes apoptosis. To expand the application of ART in materials, it is necessary to a use solution with less toxicity and side effects. For this purpose, some other auxiliary substances had been used to solubilize ART, including micelles of SDS and PVP (Lapenna et al., 2009; Zhang et al., 2017). The obtained results only showed that the solubility of ART was improved, but the total dissolution of ART was still very small and the biological effects were not investigated.

Polyethylene glycol (PEG) is a neutral polymer with special physical and chemical properties. PEG is often used as an excipient or dispersant in medical engineering, due to it being non-toxic (Ramazani et al., 2018). For example, PEG can enhance the solubility of low-watersoluble drugs, such as lornoxicam, by being synthesized 
into copolymers with drugs (Anwer et al., 2014). Based on this, the use of PEG as a co-solvent may improve the solubility of ART by hydrogen bond interaction and inhibit the recrystallization during use, which is beneficial to the pharmacological activity of ART.

This study explored solubilization of ART by PEG4000, and further investigated the biological effect of the prepared ART solution, mainly including its antibacterial properties, toxicity to normal cells, anti-inflammatory properties and anti-cancer properties.

\section{MATERIALS AND METHODS}

Materials. ART (purity $>98 \%$ ), G4000 and other chemicals (analytical grade) were purchased from Shanghai Aladdin Biochemical Technology Co., Ltd. DMEM, Trypsin-EDTA $(0.25 \%)$ and PBS were acquired from Gibco BRL, Rockville, MD, United States. MTS was purchased from Rongda Pumai Biotechnology Co., Ltd, Chongqing, China. LIVE/DEAD BacLight Bacterial Viability Kit was purchased from Molecular Probes Inc. LPS (from E. coli) and the Griess reagent were acquired from Solarbio, Beijing, China.

Preparation of the ART solution. ART was weighted and dissolved in an ethanol solution to make a $1 \mathrm{mg} /$ $\mathrm{mL}$ ART ethanol solution. The ART ethanol solution and the 12\% PEG4000 aqueous solution were mixed at 1:1 (volume ratio), and the mixture was stirred on a magnetic stirrer for 2 hours at $37^{\circ} \mathrm{C}$. Under this setting, alcohol in the mixed solution was naturally volatilized and then the mixed solution was made up to a concentration of $1 \mathrm{mg} / \mathrm{mL}$ of ART in distilled water.

Solubility studies. Ultraviolet spectrophotometry was used to measure concentration of the ART solution assisted by PEG4000 and ART solution dissolved in water (Liu et al., 2018). Firstly, 12\% PEG4000-assisted ART solution (AER-12\% PEG4000), 12\% PEG4000 solution and ART dissolved in 95\% ethanol (ART-95\% ethanol) were prepared. After centrifugation, the supernatants were scanned in the wavelength range of 200-400 $\mathrm{nm}$. The supernatant was transferred from the above three solutions into $0.2 \% \mathrm{NaOH}$ solution in a water bath $\left(50^{\circ} \mathrm{C}, 30 \mathrm{~min}\right)$ and the solutions were scanned after hydrolysis (Hydrolyzed ART-12\% PEG4000, Hydrolyzed ART-95\% ethanol, $12 \%$ PEG $\left.4000-\mathrm{NaOH} / 50^{\circ} \mathrm{C}\right)$. The maximum absorption wavelength $\left(\mathrm{W}_{\mathrm{m}}\right)$ of ART-12\% PEG4000 after hydrolysis was taken as the wavelength in solubility test.

Hydrolyzed ART-12\% PEG4000 after once, twice, three times, four times, and five times gradient dilutions (Dilution-1, Dilution-2, Dilution-3, Dilution-4, Dilution-5) were prepared in the same way and the absorbance at $\mathrm{W}_{\mathrm{m}}$ was measured. Finally, the concentration of ART-12\% PEG4000 was calculated according to the standard curve. The test was carried out at a standard atmospheric pressure and at room temperature $\left(25^{\circ} \mathrm{C}\right)$.

FTIR. FTIR spectroscopic measurements were performed using a Nicolet IS10 system in order to determine any chemical changes that occurred during formulation. Scanning range is $400 \mathrm{~cm}^{-1}-4000 \mathrm{~cm}^{-1}$ wavelength.

Antimicrobial measurement. The antimicrobial properties of the ART solution were evaluated by minimum inhibitory concentration $\left(\mathrm{MIC}_{50}\right)$. ART solutions of different concentrations $(100 \mu \mathrm{L})$ were added to a bacterial solution $\left(100 \mu \mathrm{L}, 1 \times 10^{6} \mathrm{CFU} / \mathrm{ml}\right)$, so that the final concentration of ART was $0.496 \mathrm{mg} / \mathrm{mL}, 0.248 \mathrm{mg} /$ $\mathrm{mL}, 0.125 \mathrm{mg} / \mathrm{mL}, 0.063 \mathrm{mg} / \mathrm{mL}, 0.031 \mathrm{mg} / \mathrm{mL}$, and
$0.016204 \mathrm{mg} / \mathrm{mL}$. Sterilized water $(100 \mu \mathrm{L})$ was used as a growth control, and a gentamicin solution $(100 \mu \mathrm{L}, 30$ $\mu \mathrm{g} / \mathrm{mL}$ ) was added as a positive control. The final bacterial concentration in each well was about $5 \times 10^{5} \mathrm{CFU} /$ $\mathrm{mL}$. The antibacterial rate is expressed as the rate of the reduction of bacterial concentration in the experimental group, when compared with the growth control, to the growth control group. The concentration of the drug inhibiting $50 \%$ of the bacterial growth, when compared with the growth control well, is the tested bacteria $\mathrm{MIC}_{50}$. The data was calculated by using the GraphPad Software (GraphPad, Inc, U.S.A.). The tested bacterial strains included E. coli ATCC25922, S. aureus ATCC25923, B. cereus ATCC11778 and C. albicans ATCC90028. Gentamicin was a positive control, while PEG4000 solution was a negative control.

In vitro anti-inflammatory activity. An inflammatory model was established by lipopolysaccharide-stimulated mouse macrophage cell line RAW264.7, and the anti-inflammatory ability of ART was evaluated by nitrite assay. Mouse macrophage cell line RAW264.7 was purchased from Chongqing Rongda Pumai Biotechnology Co., Ltd. All cells in this research were cultured in a DEME high sugar medium, in $5 \% \mathrm{CO}_{2}$ incubator at $37^{\circ} \mathrm{C}$. Mouse macrophages grown in $\log$ phase were seeded in a 96-well culture plate at a density of $1 \times 10^{6}$ cells/well in the DMEM medium. Fresh culture solution containing only $0.5 \mu \mathrm{g} / \mathrm{mL}$ LPS (control group) or $0.5 \mu \mathrm{g} / \mathrm{mL} \mathrm{LPS}+$ ART-12\% PEG4000 (0.031 mg/mL, $0.063 \mathrm{mg} / \mathrm{mL}, 0.125 \mathrm{mg} / \mathrm{mL}, 0.248 \mathrm{mg} / \mathrm{mL}, 0.496 \mathrm{mg} /$ $\mathrm{mL}, 0.982 \mathrm{mg} / \mathrm{mL}$ ) was added to each well, and the culture was continued for 24 hours. Then, the supernatant was transferred to a new 96-well plate, mixed with an equal volume of the Griess reaction solution, and the absorbance was measured at $542 \mathrm{~nm}$ with a microplate reader to calculate the NO release inhibition rate. Cell viability was determined using the MTS method. When the cell survival rate is $\geq 50 \%$, it can be considered that ART does have an inhibitory effect on NO.

In vitro cytotoxicity activity. Mouse fibroblast cell line L929 was generously provided by the School of Pharmacy and Bioengineering, Chongqing University of Technology, China. MTS cytotoxicity assay was performed on mouse fibroblast cell line L929 treated with the ART solution. DMEM medium containing different concentrations of ART was prepared according to the preparation method of the ART solution, and the cells were seeded at a density of $1 \times 10^{4}$ cells/well in 96-well culture plates in an ART-containing DEME medium. After $24 \mathrm{~h}$, the old culture solution was discarded, and $100 \mu \mathrm{L}$ of the DEME medium and $20 \mu \mathrm{L}$ of the MTS reagent were added to each well and mixed well. The absorbance of solution incubated for $2 \mathrm{~h}$ was measured at $490 \mathrm{~nm}$ with a microplate reader. Cell viability was also evaluated by the LIVE/DEAD double fluorescent staining Calcein AM and Ethidium homodimer-1 (EthD-1).

In vitro antitumor activity. Human liver cancer cell lines BEL-7404, SMMC-7721 and Hep G2 were generously provided by the School of Pharmacy, Southwest University, China. MTS cytotoxicity assay was performed on these three cancer cell lines treated with the ART solution. DMEM medium containing different concentrations of ART was prepared according to the preparation method of the ART solution, and the cells were seeded at a density of $1 \times 10^{4}$ cells/well in 96-well culture plates in an ART-containing DEME medium. After $24 \mathrm{~h}$, the old culture solution was discarded, and $100 \mu \mathrm{L}$ of the DEME medium and $20 \mu \mathrm{L}$ of the MTS reagent were added to each well and mixed well. The absorbance of 
a

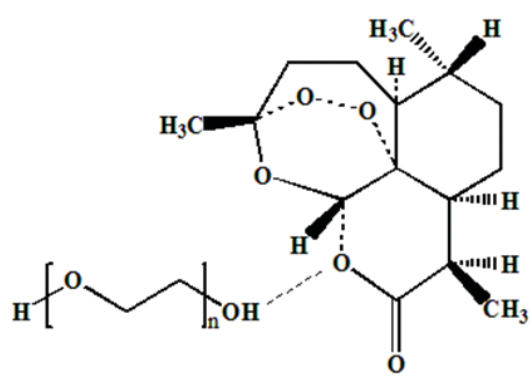

PEG

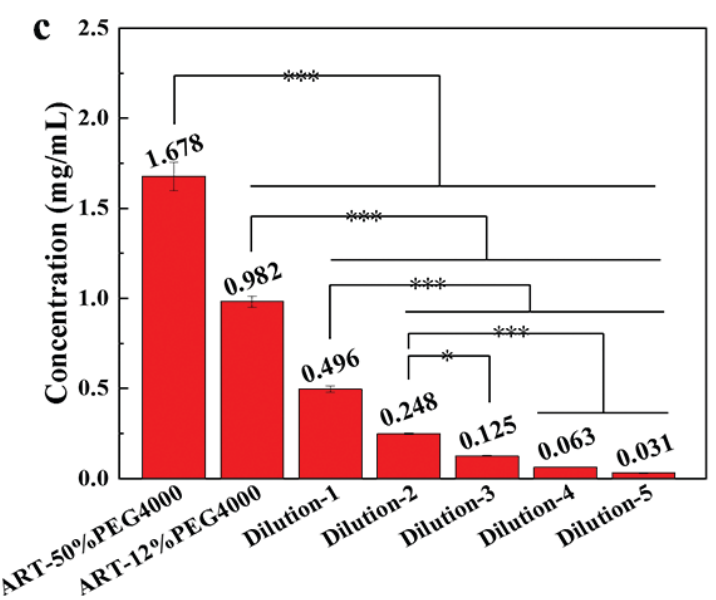

b

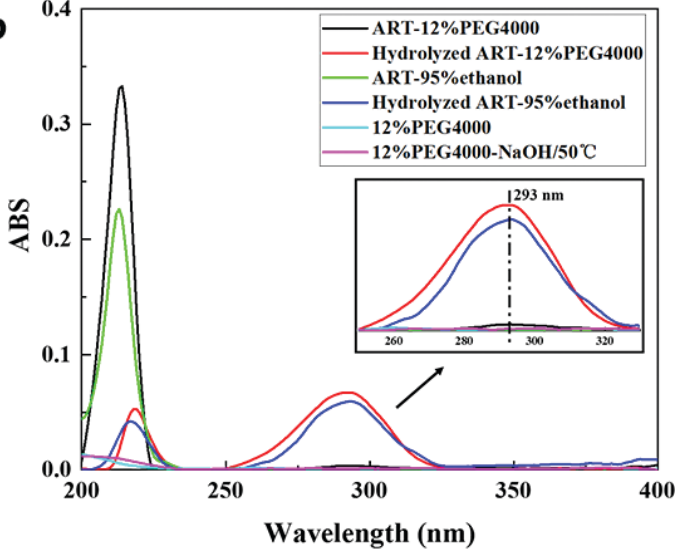

d

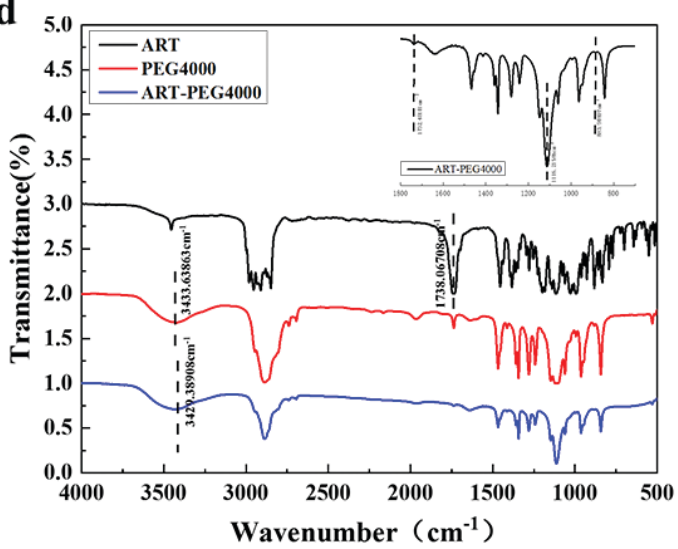

Figure 1. Analysis of the ART solutions.

(a) Mechanism for dissolving ART in PEG solution. (b) Scan spectrum curves of ART-12\% PEG, Hydrolyzed ART-12\%PEG4000, ART$95 \%$ ethanol, Hydrolyzed ART-95\% ethanol, $12 \%$ PEG4000 and $12 \%$ PEG4000-NaOH/50 ${ }^{\circ} \mathrm{C}$. (c) Solubility of ART-12\% PEG4000, ART-12\% PEG4000 and each gradient diluted ART solution. (d) FTIR spectra of PEG4000, ART, and ART-12\% PEG4000. The inset is the FTIR spectra of ART-12\% PEG4000 at $700 \mathrm{~cm}^{-1}-1800 \mathrm{~cm}^{-1}$. Data are expressed as mean \pm standard deviation ( $\mathrm{n}=9$ ). The asterisk denotes a statistically significant difference from the control group ${ }^{*} P<0.05,{ }^{* * P} P 0.01,{ }^{* *} P<0.001$.

solution incubated for $2 \mathrm{~h}$ was measured at $490 \mathrm{~nm}$ with a microplate reader. The percentage of cell viability for each treatment was calculated by adjusting the control group to $100 \%$. The inhibitory concentration $50 \%\left(\mathrm{IC}_{50}\right)$ was calculated by using the GraphPad Software (GraphPad, Inc, U.S.A.).

Significance analysis. All statistical analyses were performed by using the SPSS 16.0 software. Data were presented as mean \pm standard deviation and analyzed by one-way analysis of variance. $P$ value $<0.05$ was taken as statistically significant.

\section{RESULTS}

\section{Preparation and characterization of a solution containing ART and PEG4000}

Figure 1a indicates the mechanism for dissolving ART in PEG. High concentration of PEG in a solution can form more hydrogen bonds and thus improve the solubility of ART. We tried to use different concentrations of PEG4000 to assist ART solubility. The experiment found that $12 \%$ PEG4000 could make the solubility of ART to reach around $1 \mathrm{mg} / \mathrm{mL}$. Different concentration gradients need to be used for experiments assessing the physiological effects of the ART solution. It is appropri- ate to use $1 \mathrm{mg} / \mathrm{mL}$ ART solution as the maximum concentration for dilution to find the best application concentration. Gradient dilutions of ART-12\% PEG4000 are shown in Fig. S1 (at https://ojs.ptbioch.edu.pl/index.php/abp/). All of the diluted solutions were clear and transparent while ART was insoluble in water (red frame). However, obvious white crystal precipitations occurred at $2 \mathrm{mg} / \mathrm{mL}$ ART-12\% PEG4000. Moreover, these ART solutions could remain clear after storage at 4 ${ }^{\circ} \mathrm{C}$ or at room temperature for 7 days.

\section{Solubility of ART assisted by PEG4000}

In order to characterize the solubility of ART, UV wavelength scanning was performed on the solution before and after hydrolysis of ART-12\% PEG4000, 12\% PEG4000 and ART-95\% ethanol (Fig. 1b). Both, the hydrolyzed ART-12\% PEG4000 and hydrolyzed ART95\% ethanol solutions had a maximum absorption peak at $293 \mathrm{~nm}$, and this wavelength can be used to characterize the solubility of ART (Fig. 1c). The maximum solubility of ART in $12 \%$ PEG4000 was $0.982 \pm 0.089$ $\mathrm{mg} / \mathrm{mL}$ and the concentration became $0.496 \pm 0.046$ $\mathrm{mg} / \mathrm{mL}, \quad 0.248 \pm 0.011 \mathrm{mg} / \mathrm{mL}, \quad 0.125 \pm 0.009 \mathrm{mg} / \mathrm{mL}$, $0.063 \pm 0.005 \mathrm{mg} / \mathrm{mL}$ and $0.031 \pm 0.007 \mathrm{mg} / \mathrm{mL}$, after equal volume dilution for once, twice, three times, four times and five times dilutions at $25^{\circ} \mathrm{C}$ and standard atmospheric pressure, respectively. The solubility of ART 

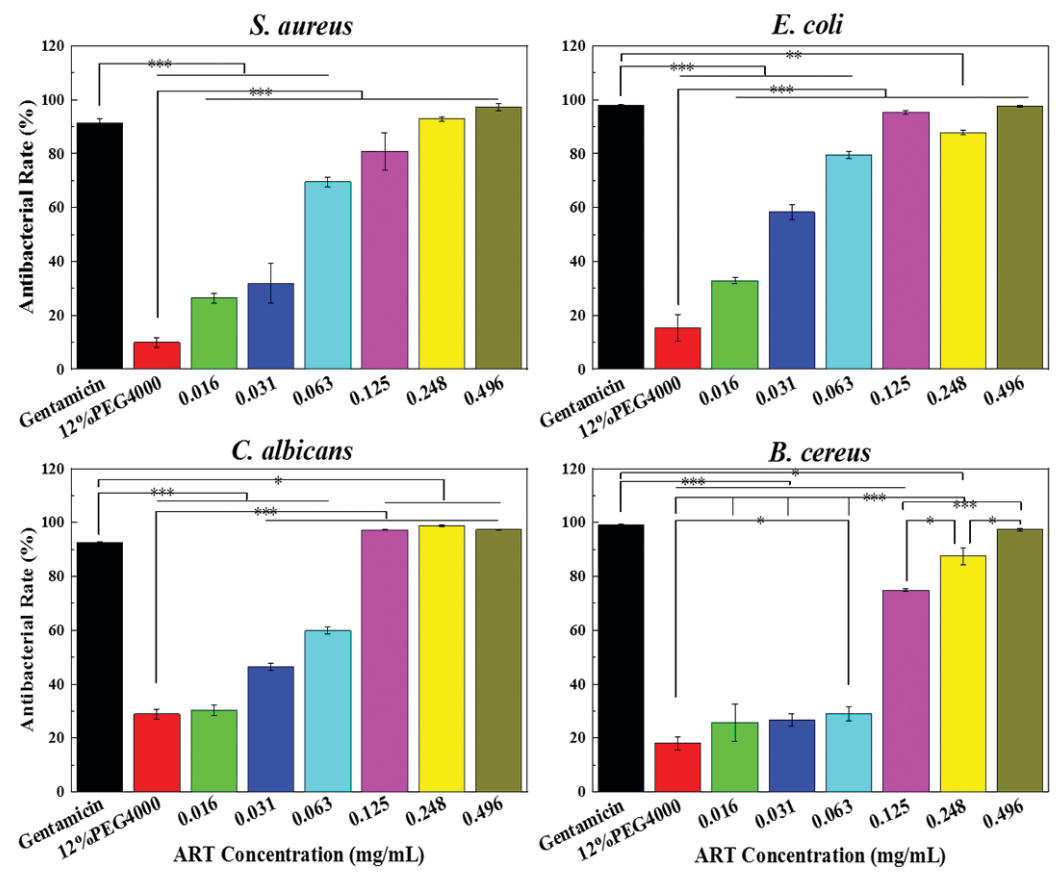

Figure 2. The antibacterial effect of different concentrations of the ART solutions on S. aureus, E. coli, B. cereus and fungi C. albicans. Data are expressed as mean \pm standard deviation $(n=3)$. The asterisk denotes a statistically significant difference from the control group ${ }^{*} P<0.05,{ }^{* *} P<0.01,{ }^{* * *} P<0.001$.

had increased with increasing concentration of PEG4000. The $1.678 \pm 0.241 \mathrm{mg} / \mathrm{mL}$ ART solution could be obtained when the PEG4000 content is at $50 \%$.

\section{FTIR assay of ART assisted by PEG4000}

The interaction between PEG4000 and ART-12\% PEG4000 was characterized by the FTIR spectrum. The FTIR spectrum of the aqueous ART solution (Fig.1d) showed $\mathrm{C}=\mathrm{O}$ stretching vibration due to a lactone at $1732 \mathrm{~cm}^{-1}$ and a stretching vibration at $883,1117 \mathrm{~cm}^{-1}$ due to peroxide. It is evident that the PEG OH stretching $\left(3433 \mathrm{~cm}^{-1}\right)$ and ART CO vibrations $\left(1738 \mathrm{~cm}^{-1}\right)$ moved to $3429 \mathrm{~cm}^{-1}$ and $1732 \mathrm{~cm}^{-1}$, respectively, in the ART solution, possibly due to hydrogen bonds between PEG4000 and ART. Cooperation of the hydroxy compounds causes the interaction between the hydroxyl groups of polyethylene glycol and the ester groups of ART. The characteristic peak of the peroxide bridge that appeared in the ART solution without any deviation means the structure of ART is basically unchanged, which can maximize the performance of ART.

\section{Antimicrobial performance of ART assisted by PEG4000}

The antimicrobial activity of ART-12\% PEG4000 against E. coli, B. cereus, S. aureus and fungi C. albicans was determined by antibacterial rate (Fig. 2). ART solu-

Table 1. The minimum inhibitory concentration of ART solution for four strains.

\begin{tabular}{ll}
\hline Strain & $\mathrm{MIC}_{50}[\mathrm{mg} / \mathrm{mL}]$ \\
\hline S. aureus (ATCC25923) & 0.039 \\
\hline B. cereus (ATCC11778) & 0.068 \\
\hline E. coli (ATCC25922) & 0.022 \\
\hline C. albicans (ATCC90028) & 0.030 \\
\hline
\end{tabular}

tions with high concentration have a significant inhibitory effect on S. aureus, B. cereus, E. coli and C. albicans, while the blank control (PEG4000 solution) shows no antimicrobial activity (Fig. S2 at https://ojs.ptbioch.edu. $\mathrm{pl} /$ index.php/abp/). The antibacterial rates of the ART solution for $S$. aureus, B. cereus, E. coli and C. albicans were $97.343 \%, 97.338 \%, 97.688 \%$ and $97.309 \%$, respectively, and show dose dependence. Further, the minimum inhibitory concentrations $\left(\mathrm{MIC}_{50}\right)$ for three bacteria and a fungus were measured (Table 1). $\mathrm{MIC}_{50}$ for $S$. aureus and $B$. cereus (Gram-positive bacteria) is $0.039 \mathrm{mg} / \mathrm{mL}$ and $0.068 \mathrm{mg} / \mathrm{mL}$, respectively, for E. coli (Gram-negative bacteria) it is $0.022 \mathrm{mg} / \mathrm{mL}$, and for C. albicans (fungi) it is $0.030 \mathrm{mg} / \mathrm{mL}$. This means that lower concentrations of the ART solution have a better inhibitory effect on Gram-negative bacteria, while Gram-positive bacteria and fungi are more resistant to ART.

\section{In vitro anti-inflammatory properties}

LPS-stimulated RAW264.7 cell line was established as an in vitro inflammation model to evaluate the antiinflammatory effects of ART. Inhibitory effect of the ART solution on the inflammatory response was demonstrated by detecting the production of NO in inflammatory mediators (Fig. 3). The RAW264.7 cell line stimulated by LPS released a large amount of NO, which was far beyond the release of $\mathrm{NO}$ in normal cells. All of the tested ART solutions had a significant inhibitory effect on NO production in the RAW264.7 cells, which indicated that they have an effective anti-inflammatory activity. It is worth noting that the PEG4000 solution also had a certain inhibitory effect on the release of NO, but the inhibitory effect of ART on inflammation was still stronger than that in the LPS-stimulated PEG test group. Further, cytotoxicity of the ART solution to the RAW264.7 cells was evaluated by the MTS method, and the purpose was to determine its inhibitory effect on inflammatory response that was caused by its inhibitory 

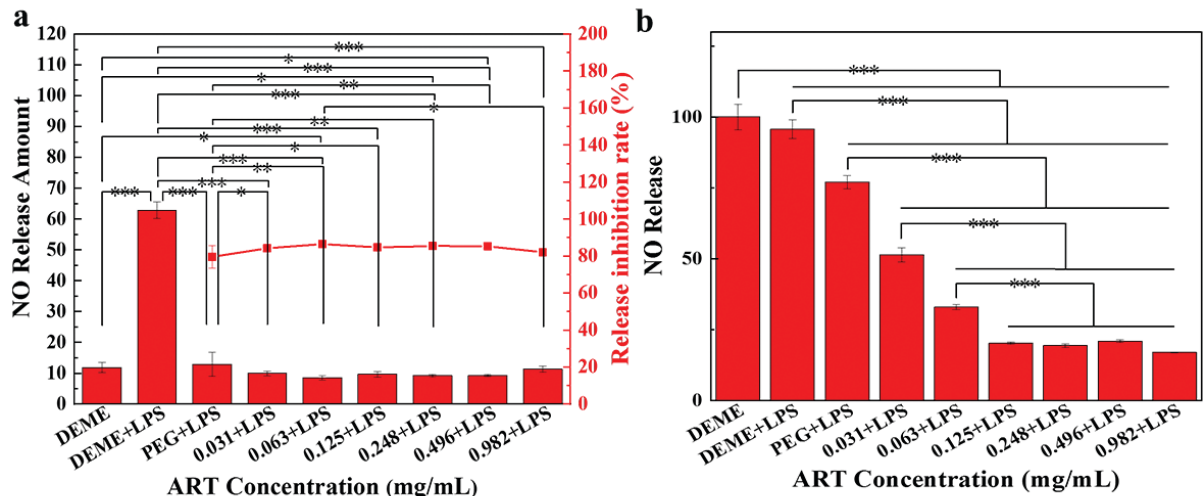

Figure 3. Analysis of anti-inflammatory property of the ART solutions.

(a) ART solution inhibition of NO production in LPS-stimulated RAW264.7 cells. The histogram is the amount of NO released, and the line graph is the NO release inhibition rate. (b) Cytotoxicity of ART towards RAW264.7 cells estimated by MTS assay. LPS-stimulated RAW264.7 cells were incubated with designated doses of ART solution for $24 \mathrm{~h}$. Data are expressed as mean \pm standard deviation $(\mathrm{n}=5)$. The asterisk denotes a statistically significant difference from the control group ${ }^{*} P<0.05,{ }^{* *} P<0.01,{ }^{* * *} P<0.001$.

activity or cytotoxicity. Cytotoxicity of the ART solution to RAW264.7 cells was gradually enhanced with increasing ART concentrations. Only cells treated with 0.031 $\mathrm{mg} / \mathrm{mL}$ ART solution had a survival rate greater than $50 \%$, which meant that the ART solution had an inhibitory effect on NO release and a significant anti-inflammatory effect.

\section{In vitro cytotoxicity analysis}

Mouse fibroblast L929 cell line was used to detect cytotoxicity of the prepared ART solutions by the MTS method. The results indicated that the low concentration of ART $(0.031-0.063 \mathrm{mg} / \mathrm{mL})$ had no toxicity towards the cells (cell activity was more than 80\%) (Fig. 4a).

a

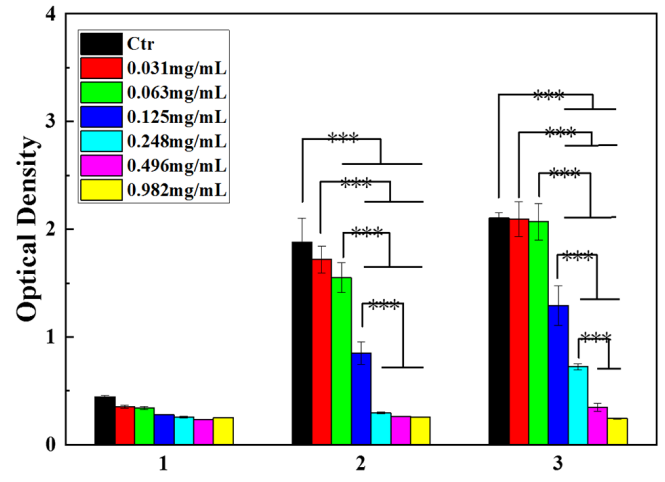

Time (day)

b
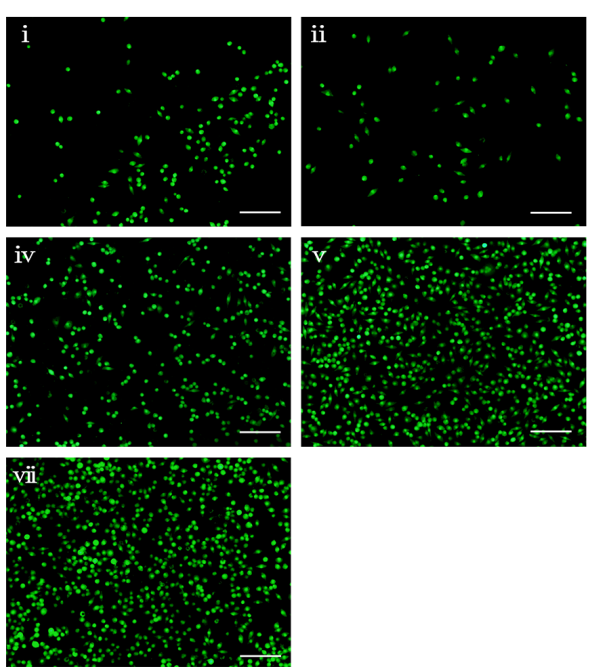
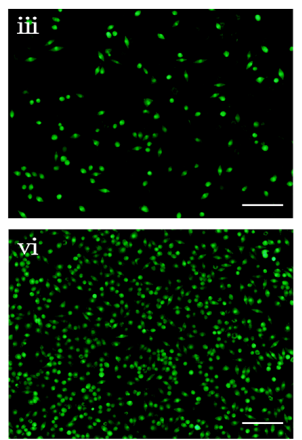

Figure 4. Cytotoxicity analysis of the ART solutions.

(a) Cytotoxicity of ART towards normal L929 cells assessed by MTS assay. (b) Life and death cell staining of L929 cells treated with ART. The concentration of ART solution is (i) $0.982 \mathrm{mg} / \mathrm{mL}$, (ii) $0.496 \mathrm{mg} / \mathrm{mL}$, (iii) $0.248 \mathrm{mg} / \mathrm{mL}$, (iv) $0.125 \mathrm{mg} / \mathrm{mL}$, (v) $0.063 \mathrm{mg} / \mathrm{mL}$, (vi) 0.031 $\mathrm{mg} / \mathrm{mL}$ and (vii) control group. The control group used the cosolvent PEG4000. Data are expressed as mean \pm standard deviation ( $\mathrm{n}=3$ ). The asterisk denotes a statistically significant difference from the control group ${ }^{*} P<0.05,{ }^{* *} P<0.01,{ }^{* * *} P<0.001$. 

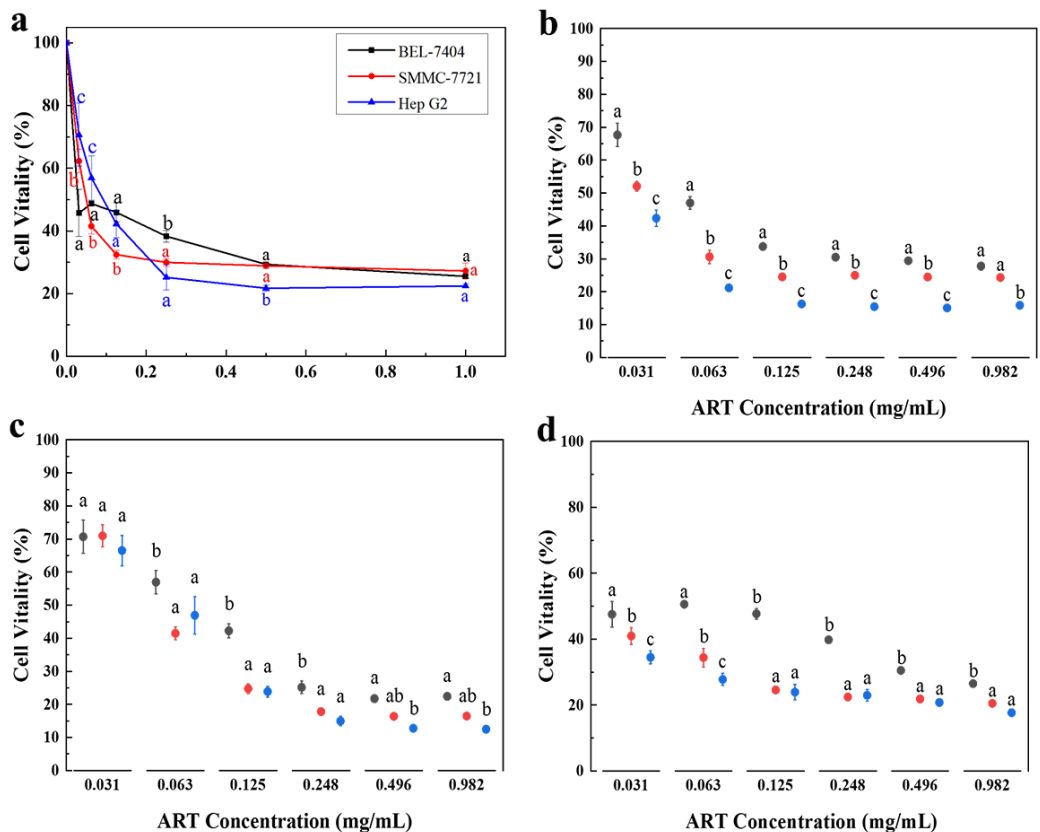

Figure 5. In vitro antitumor properties of the ART solutions

(a) Effects of ART on cell viability of three types of cancer cells for 24 h; Effects of ART on cell viability of cancer cells (b) SMMC-7721, (c) Hep G2 and (d) BEL-7404 for 3 days, respectively. Cancer cells SMMC-7721, Hep G2 and BEL-7404 were incubated with designated doses of ART solution for $24 \mathrm{~h}$ and 3 days. Data are expressed as mean \pm standard deviation ( $\mathrm{n}=3$ ). Letters indicate levels of significant difference between groups. Among the averages, there is no significant difference between those with the same marked letter, and significant differences between those with different marked letters.

Cytotoxicity towards L929 cells had increased with the increasing ART concentrations. Activity of cells treated with different concentration of ART solution showed a dose-dependent effect.

The results of life and death cell staining of the L929 cells treated with the ART solutions showed that these solution could lead to cell death (Fig. 4b). After exposure to high concentrations of ART solution, the L929 cells died in large numbers. After cells were exposed to $0.031 \mathrm{mg} / \mathrm{mL}$ or $0.063 \mathrm{mg} / \mathrm{mL}$ ART, the cell viability can reach $80 \%$ or more. All of the results from LIVE/ DEAD staining indicated that cell viability of the L929 cells had decreased in a dose-dependent manner after cells were exposed to ART, and the results were consistent with the MTS test results. Based on the above experimental results, it could be confirmed that the concentration of the ART solution dissolved in the $12 \%$ PEG4000 should not exceed $0.063 \mathrm{mg} / \mathrm{mL}$ when applied in biology.

\section{In vitro antitumor properties}

Viability of the BEL-7404, SMMC-7721 and Hep G2 human hepatoma cells treated with different concentrations of the ART solution was characterized to determine effect of the ART solution on cancer cells. As shown in Fig. 5a, the ART solution could significantly inhibit the three cancer cell lines after cells were exposed to ART for $24 \mathrm{~h}$, and the cell activity decreased sharply with increased concentration of ART. During 3 days of culture, ART keeps acting on cancer cells and effectively inhibits growth of cancer cells (Fig. 5b, c, d). The $\mathrm{IC}_{50}$ of ART on BEL-7404, SMMC-7721 and Hep G2 cells was $0.0016 \mathrm{mg} / \mathrm{mL}, 0.0084 \mathrm{mg} / \mathrm{mL}$ and $0.0541 \mathrm{mg} / \mathrm{mL}$, respectively. In other words, BEL-7404 cancer cells were the most sensitive to ART.

\section{DISCUSSION}

The ART molecule has a large carbon skeleton and no hydrophilic groups, which makes the hydrophobic property dominant. ART's clinical application is limited by the characteristic poor water solubility. To solve this problem, ART derivatives are often synthesized. There have been few studies on improving solubility to ensure the physiological activity of ART. Based on this, PEG4000 was used to improve the solubility of ART. The experimental results were compared with the existing studies in the Table 2. The commonly used co-solvent DMSO has greater biological toxicity, and the solubility of ART is lower at a safe DMSO concentration $(1 \%)$. The solubility of ART is significantly increased with the help of organic solvents, but the biological effects are not studied. In our study, PEG4000 was used as the co-solvent, which not only avoided the side effects of the co-solvent, but also significantly increased the solubility of ART., 50\% PEG4000 makes ART solubility reach $1.678 \mathrm{mg} / \mathrm{mL}$, which is equivalent to the effect of SDS-assisted ART solubility.

The ART-12\% PEG4000 solution can effectively inhibit growth of microorganisms although the antimicrobial mechanism of ART is not clear yet. It is speculated that the free radicals formed by the breaking of the oxygen bridge of ART molecules have destructive effects on cell membrane, DNA and other intracellular substances. Some studies have proven that ART can change the permeability of the bacterial cell membrane and cause irreversible damage to the cell membrane. This leads to leakage of DNA, ATP and proteins, which ultimately kills bacteria (Lin et al., 2018). Our results differed from those of Suganthi, who noted that Gram-positive bacteria were more resistant to ART extracts (Appalasamy et al., 2014). The possible reason is the solvent used for dissolving ART. The main difference between Gram- 
Table 2. Solubility of ART in different solvents.

\begin{tabular}{|c|c|c|c|c|}
\hline Name & $\begin{array}{l}\text { Solvent/ } \\
\text { Cosolvent }\end{array}$ & Concentration & $\begin{array}{l}\text { Pharmacological activity/ } \\
\text { Solubilization mechanism }\end{array}$ & References \\
\hline ART & $\mathrm{H}_{2} \mathrm{O}$ & $0.082 \mathrm{mg} / \mathrm{mL}$ & & (Gao et al., 2013) \\
\hline ART & DMSO/* & $\begin{array}{l}\text { ART }\left(3.075 \times 10^{-5}-0.038\right. \\
\mathrm{mg} / \mathrm{mL})\end{array}$ & $\begin{array}{l}\text { Inhibition of cell activity of six AML cell lines by } \\
\text { dose-dependent method }\end{array}$ & (Drenberg et al., 2016) \\
\hline ART & DMSO/* & $\begin{array}{l}0.014-0.282 \mathrm{mg} / \mathrm{mL} \\
(\mathrm{DMSO}<0.25 \%)\end{array}$ & $\begin{array}{l}\text { Dose-dependent cytotoxicity in } \mathrm{Hbe} \text { and A549 } \\
\text { cells, selective to A549 }\end{array}$ & (Li et al., 2018) \\
\hline ART & $\mathrm{D}_{2} \mathrm{O} / \mathrm{SDS}$ micelles & $\begin{array}{l}1.694 \mathrm{mg} / \mathrm{mL} \\
\text { (SDS } 11.535 \mathrm{mg} / \mathrm{mL})\end{array}$ & $\begin{array}{l}\text { *Containing ART lipophilic molecules in the hy- } \\
\text { drophobic core of the SDS }\end{array}$ & (Lapenna et al., 2009) \\
\hline ART & $\mathrm{D}_{2} \mathrm{O} / \mathrm{PVP}$ & $\begin{array}{l}\approx 0.270 \mathrm{mg} / \mathrm{mL} \\
(P V P 428.570 \mathrm{mg} / \mathrm{mL})\end{array}$ & $\begin{array}{l}\text { *Dipole-dipole interaction between an amide } \\
\text { group and an ester group }\end{array}$ & (Zhang et al., 2017) \\
\hline ART & $\mathrm{H}_{2} \mathrm{O} / \mathrm{PEG} 4000$ & $\begin{array}{l}0.982 \mathrm{mg} / \mathrm{mL} \\
\text { (PEG4000 } 136.360 \mathrm{mg} / \mathrm{mL})\end{array}$ & $\begin{array}{l}\text { Antibacterial, anti-inflammatory, cytotoxic to } \\
\text { cancer cells by dose-dependent method. Co- } \\
\text { operation of hydroxy compounds causes the } \\
\text { interaction between the hydroxyl groups of } \\
\text { PEG4000 and the ester groups of ART }\end{array}$ & Current research \\
\hline
\end{tabular}

${ }^{*}$ means no research or no explanation in pharmacological activity.

positive and Gram-negative bacteria is the cell wall permeability. In terms of Gram-negative bacteria, such as E. coli, there is an efflux pump AcrB in the cell membrane that can inhibit the entry of antibiotics and accelerate their excretion (Sun et al., 2014). Thus, Gram-negative bacteria usually exhibit better resistance to antibiotics (Wu et al., 2013). But in this study, the introduction of PEG4000 solution possibly changed the permeability of the cell membrane and reduced the function of the efflux pump. In addition, PEG can change biofilm structure when acting on cells and viruses, and can mediate evacuation and rearrangement of lipid molecules (Lentz \& Lee, 1999). The cell wall of Gram-negative bacteria contains lipopolysaccharides, lipoproteins and a lipid bilayer. When PEG4000 acts, the lipid molecules on the surface of the bacteria are evacuated and rearranged, which is beneficial for the entry of ART into the bacteria (Fig. 6). Therefore, the prepared solution exhibits a higher antimicrobial activity towards Gram-negative bacteria (Ceylan et al., 2013).

A large number of studies has proven that ART and its derivatives have immunomodulatory properties, which means that they have significant effects on a variety of immune cells (Yao et al., 2016). We validated the anti-inflammatory effects of the ART solution after increasing its solubility by constructing an inflammation model using a mouse macrophage cell line RAW264.7. ART can disrupt macrophage-associated homeostasis by interfering with transcriptional signaling pathways in macrophages, thereby inhibiting the synthesis of inducible $\mathrm{NO}$ enzymes and reducing the release of TNF- $\alpha$, IL- 6 and NO (Li et al., 2012). The pro-inflammatory factor NO is a

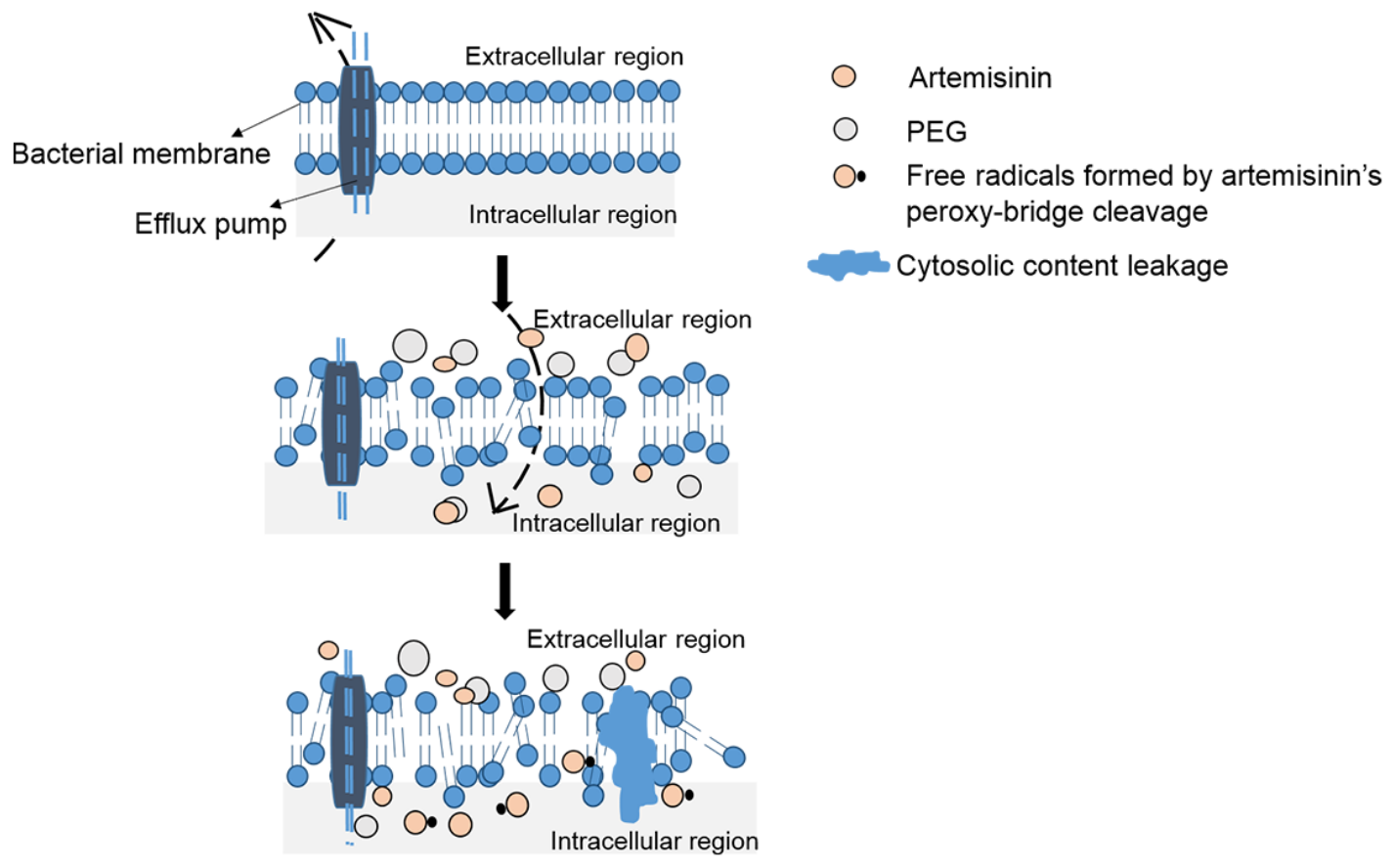

Figure 6. Schematic diagram of antibacterial mechanism of the ART solution. 
gas radical generated by L-arginine catalyzed by nitric oxide synthetase, and a large amount of NO is generated when the cells are stimulated by an immune microorganism to cause an inflammatory reaction. NO can form reactive oxygen species and reactive nitrogen free radicals can attack biomacromolecules and aggravate inflammatory reactions (Hussain et al., 2004). The anti-inflammatory effect of the ART solution on mouse macrophages may be due to the down-regulation of IFN- $\beta /$ STAT-1 signaling by inhibition of IFN- $\beta$ expression, which leads to the inhibitory effect of ART on LPS-induced NO production (Park et al., 2012). Our study shows that a low concentration of the ART solution could effectively inhibit production of the inflammatory reaction, which provides some support for future applications of ART.

ART has obvious inhibitory effects on various cancer cells, but also has toxic effects on normal cells (Posobiec et al., 2013). The iron and heme contained in normal cells may destroy the peroxide bridge of ART to form free radicals. These free radicals cause oxidative damage to cells and affect cell proliferation (Wang \& Yi, 2008). This cytotoxicity is not relative to solvent used for the ART solution (Li et al., 2018). In general, the effect of ART solution on cells is dose-dependent, which is consistent with other researchers' conclusion (Houh et al., 2017). In addition, ART has obvious selective effects on normal cells and cancer cells. The mechanism of anticancer cells is basically the same as that of normal cells. The reason for the different inhibition efficiency is that the tumor cells or cancer cells contain more iron. The occurrence of tumors and cancer is usually accompanied by an abnormal increase in iron, and the iron-rich environment will intensify the proliferation of cancer cells, resulting in much higher iron content in cancer cells than normal cells (Iancu et al., 1988; Nekhai \& Gordeuk, 2012). The cleavage of ART over-oxygen bridge mainly relies on an iron element. The iron-rich environment in cancer cells can effectively promote the cleavage of ART to form a large amount of ROS, which activates excessive oxidative damage of cellular DNA. Therefore, the inhibitory effect of ART solution on cancer cells is much higher. The three types of cancer cells used in this study were all human liver cancer cells, which to some extent reduced the impact of the differences of different types of tissues. However, the experimental results confirmed that the selectivity of ART solution to three types of cancer cells could be up to 33 times. Cancer therapy is a potential application of ART. This supports the targeted application of ART. However, the concentration and the mode of administration have to be explored in future studies.

In summary, this study proves that ART can be solubilized by PEG4000. The maximum concentration of ART in $12 \%$ PEG4000 is around $1 \mathrm{mg} / \mathrm{mL}$. Further, investigation of its biological properties indicates that the prepared ART solution has a significant inhibitory effect on different microorganisms. Also, ART has a significant anti-inflammatory effect. The level of released inflammatory factor NO by ART-treated inflammatory cells is significantly inhibited. ART has no obvious cytotoxicity but has an anti-cancer property. The sensitivity of normal cells and cancer cells (SMMC-7721 \& Hep G2 \& BEL7404) to ART is dose-dependent, and ART also has selective effects on different cancer cells. In addition, the biological functions of ART mentioned above can be achieved when the ART concentration is at $0.031 \mathrm{mg} /$ $\mathrm{mL}$. These results lay a foundation for broadening the application of ART in pharmaceutics, biomaterials and medicine.

\section{Conflicts of Interest}

None.

\section{REFERENCES}

Abba ML, Patil N, Leupold JH, Saeed MEM, Efferth T, Allgayer H (2018) Prevention of carcinogenesis and metastasis by Artemisinintype drugs. Cancer Lett. 429: 11-18. https://doi.org/10.1016/j.canlet.2018.05.008

Abou Rayia DM, Saad AE, Ashour DS, Oreiby RM (2017) Implication of artemisinin nematocidal activity on experimental trichinellosis: In vitro and in vivo studies. Parasitol. Int. 66: 56-63. https://doi. org/10.1016/j.parint.2016.11.012

Anwer MK, Jamil S, Ansaria MJ, Al-Shdefata R, Alia BE, Ganaieb MA, Abdel-Kader MS, Shakeele F (2014) Water soluble binary and ternary complexes of diosmin with $\beta$-cyclodextrin: Spectroscopic characterization, release studies and anti-oxidant activity. J. Mol. Liq. 199: 35-41. https://doi.org/10.1016/i.molliq.2014.08.012

Appalasamy S, Lo KY, Ch'Ng SJ, Nornadia K, Othman AS, Chan LK (2014) Antimicrobial activity of artemisinin and precursor derived from in vitro plantlets of Artemisia annua L. Biomed Res. Int. 2014: 1-6. https://doi.org/10.1155/2014/215872

Barradell LB, Fitton A (1995) Artesunate: A review of its pharmacology and therapeutic efficacy in the treatment of malaria. Drugs. 50: 714-741. https://doi.org/10.2165/00003495-199550040-00009

Ceylan HA, Türkan I, Sekmen AH (2013) Effect of coronatine on antioxidant enzyme response of chickpea roots to combination of PEG-induced osmotic stress and heat stress. J. Plant Growth Regul. 32: 72-82. https://doi.org/10.1007/s00344-012-9277-5

Drenberg CD, Buaboonnam J, Orwick SJ, Hu S, Li L, Fan Y, Shelat AA, Guy RK, Rubnitz J, Baker SD (2016) Evaluation of artemisinins for the treatment of acute myeloid leukemia. Cancer Chemother. Pharmacol. 77: 1231-1243. https://doi.org/10.1007/s00280016-3038-2

Ganguli A, Choudhury D, Datta S, Bhattacharya S, Chakrabarti G (2014) Inhibition of autophagy by chloroquine potentiates synergistically anti-cancer property of artemisinin by promoting ROS dependent apoptosis. Biochimie. 107: 338-349. https://doi.org/10.1016/j. biochi.2014.10.001

Gao W, Luan S, Wang R, Zhang S (2013) Determination of equilibrium solubility and apparent octanol/water partition coefficient of artemisinin in different solvents. Drug Eval. Res. 1: 35-38. https:// doi.org/10.7501/j.issn.1674-6376.2013.01.009

Houh YK, Kim KE, Park S, Hur DY, Kim S, Kim D, Bang SI, Yang Y, Park HJ, Cho D (2017) The effects of artemisinin on the cytolytic activity of natural killer (NK) cells. Int. J. Mol. Sci. 18: 1600. https://doi.org/10.3390/ijms18071600

Hussain SP, Trivers GE, Hofseth LJ, He P, Shaikh I, Mechanic LE, Doja S, Jiang W, Subleski J, Shorts L, Haines D, Laubach VE, Wiltrout RH, Djurickovic D, Harris CC (2004) Nitric oxide, a mediator of inflammation, suppresses tumorigenesis. Cancer Res. 64: 68496853. https://doi.org/10.1158/0008-5472.CAN-04-2201

Iancu TC, Shiloh H, Kedar A (1988) Neuroblastomas contain ironrich ferritin. Cancer. 61: 2497-2502. https://doi.org/10.1002/10970142(19880615)61:12<2497::AID-CNCR2820611218>3.0.CO;2-P

Jia J, Qin Y, Zhang L, Guo C, Wang Y, Yue X, Qian J (2016) Artemisinin inhibits gallbladder cancer cell lines through triggering cell cycle arrest and apoptosis. Mol. Med. Rep. 13: 4461-4468. https:// doi.org/10.3892/mmr.2016.5073

Lapenna S, Bilia AR, Morris GA, Nilsson M (2009) Novel artemisinin and curcumin micellar formulations: Drug solubility studies by NMR spectroscopy. J. Pharm. Sci. 98: 3666-3675. https://doi. org/10.1002/jps.21685

Lentz BR, Lee JK (1999) Poly(ethylene glycol) (PEG)-mediated fusion between pure lipid bilayers: A mechanism in common with viral fusion and secretory vesicle release? Mol. Membr. Biol. 16: 279-296. https://doi.org/10.1080/096876899294508

Li T, Chen H, Wei N, Mei X, Zhang S, Liu DL, Gao Y, Bai SF, Liu $\mathrm{XG}$, Zhou YX (2012) Anti-inflammatory and immunomodulatory mechanisms of artemisinin on contact hypersensitivity. Int. Immunopharmacol. 12: 144-150. https://doi.org/10.1016/j.intimp.2011.11.004

Li X, Zhou Y, Liu Y, Zhang X, Chen T, Chen K, Ba Q, Li J, Liu H, Wang H (2016) Preclinical efficacy and safety assessment of artemisinin-chemotherapeutic agent conjugates for ovarian cancer. EBioMedicine. 14: 44-54. https://doi.org/10.1016/j.ebiom.2016.11.026

Li X, Gu S, Sun D, Dai H, Chen H, Zhang Z (2018) The selectivity of artemisinin-based drugs on human lung normal and cancer cells. Environ. Toxicol. Pharmacol. 57: 86-94. https://doi.org/10.1016/j. etap.2017.12.004

Lin L, Mao X, Sun Y, Cui H (2018) Antibacterial mechanism of artemisinin/beta-cyclodextrins against methicillin-resistant Stapbylococcus aureus (MRSA). Microb. Pathog. 118: 66-73. https://doi.org/10.1016/j. micpath.2018.03.014 
Liu L, Liu Y, Ma L, Mao F, Jiang A, Liu D, Wang L, Jia Q, Zhou J (2018) Artemisinin-Loaded Mesoporous Nanoplatform for $\mathrm{pH}$ Responsive Radical Generation Synergistic Tumor Theranostics. ACS Appl. Mater. Interfaces. 10: 6155-6167. https://doi.org/10.1021/ acsami.7b18320

Liu Y, Lü H, Pang F (2009) Solubility of artemisinin in seven different pure solvents from (283.15 to 323.15) K. J. Chem. Eng. Data. 54 762-764. https://doi.org/10.1021/je800515w

Nekhai S, Gordeuk VR (2012) Iron metabolism in cancer and infection. Iron Physiology and Pathophysiology in Humans. Anderson GJ \& McLaren GD eds., pp. 477-495. Humana Press. https://doi. org/10.1007/978-1-60327-485-2_24

Paeshuyse J, Coelmont L, Vliegen I, Van hemel J, Vandenkerckhove J, Peys E, Sas B, De Clercq E, Neyts J (2006) Hemin potentiates the anti-hepatitis $C$ virus activity of the antimalarial drug artemisinin. Biochem. Biophys. Res. Commun. 348: 139-144. https://doi. org/10.1016/j.bbrc.2006.07.014

Park KH, Yoon YD, Han SB, Oh SJ, Yun J, Lee CW, Lee K, Park SK, Kim HM, Kang JS (2012) Artemisinin inhibits lipopolysaccharide-induced interferon- $\beta$ production in RAW 264.7 cells: Implications on signal transducer and activator of transcription-1 signaling and nitric oxide production. Int. Immunopharmacol. 14: 580-584. https://doi.org/10.1016/j.intimp.2012.09.012

Posobiec LM, Clark RL, Bushdid PB, Laffan SB, Wang KF, White TEK (2013) Dihydroartemisinin (DHA) treatment causes an arrest of cell division and apoptosis in rat embryonic erythroblasts in whole embryo culture. Birth Defects Res. Part B-Dev. Reprod. Toxicol. 98: 445-458. https://doi.org/10.1002/bdrb.21088

Ramazani A, Keramati M, Malvandi H, Danafar H, Kheiri Manjili H (2018) Preparation and in vivo evaluation of anti-plasmodial properties of artemisinin-loaded PCL-PEG-PCL nanoparticles. Pharm. Dev. Technol. 23: 911-920. https://doi.org/10.1080/10837450.2017. 1372781

Riganti C, Doublier S, Viarisio D, Miraglia E, Pescarmona G, Ghigo D, Bosia A (2009) Artemisinin induces doxorubicin resistance in human colon cancer cells via calcium-dependent activation of HIF$1 \alpha$ and P-glycoprotein overexpression. Br. J. Pharmacol. 156: 1054 1066. https://doi.org/10.1111/j.1476-5381.2009.00117.x

Sun J, Deng Z, Yan A (2014) Bacterial multidrug efflux pumps: Mechanisms, physiology and pharmacological exploitations. Bio- chem. Biophys. Res. Commun. 453: 254-267. https://doi.org/10.1016/j. bbrc.2014.05.090

Svensson USH, Sandström R, Carlborg Ö, Lennernäs H, Ashton M (1999) High in situ rat intestinal permeability of artemisinin unaffected by multiple dosing and with no evidence of P-glycoprotein involvement. Drug Metab. Dispos. 27: 227-232

Tu Y (1999) The development of new antimalarial drugs: Qinghaosu and dihydro-qinghaosu. Chin. Med. J. (Engl). 112: 976-977. https:// doi.org/10.3760/j.issn:0366-6999.1999.11.004

You-You T, Mu-Yun N, Yu-Rong Z, Lan-Na L, Shu-Lian C, MuQun Z, Xiu-Zhen W, Zheng J, Xiao-Tian L (2015) Studies on the constituents of Artemisia annua L. Yao Xue Xue Bao. 50: 366-370. https://doi.org/10.1055/s-2007-971424

Van Agtmael MA, Eggelte TA, Van Boxtel CJ (1999) Artemisinin drugs in the treatment of malaria: From medicinal herb to registered medication. Trends Pharmacol. Sci. 20: 199-205. https://doi. org/10.1016/S0165-6147(99)01302-4

Wang J, Yi J (2008) Cancer cell killing via ROS: To increase or decrease, that is a question. Cancer Biol. Ther. 7: 1875-1884. https:// doi.org/10.4161/cbt.7.12.7067

Wong JW, Yuen KH (2001) Improved oral bioavailability of artemisinin through inclusion complexation with $\beta$ - and $\gamma$-cyclodextrins. Int. J. Pharm. 227: 177-185. https://doi.org/10.1016/S03785173(01)00796-7

Wu C, Liu J, Pan X, Xian W, Li B, Peng W, Wang J, Yang D, Zhou $H$ (2013) Design, synthesis and evaluation of the antibacterial enhancement activities of amino dihydroartemisinin derivatives. Molecules. 18: 6866-6882. https://doi.org/10.3390/molecules18066866

Yao W, Wang F, Wang H (2016) Immunomodulation of artemisinin and its derivatives. Sci. Bull. 61: 1399-1406. https://doi. org/10.1007/s11434-016-1105-z

Zhang J, Guo R, He A, Weng S, Gao X, Xu Y, Noda I, Wu J (2017) Investigation on the relationship between solubility of artemisinin and polyvinylpyrroli done addition by using DAOSD approach. Spectrochim. Acta - Part A Mol. Biomol. Spectrosc. 182: 136-142. https://doi.org/10.1016/j.saa.2017.03.062 